\title{
BECOMING A FOLLOWER OF CHRIST: EXPLORING CONVERSION THROUGH HISTORICAL AND MISSIOLOGICAL LENSES
}

\author{
RUPEN DAS * \\ International Baptist Theological Study Centre \& Vrije Universiteit, Amsterdam
}

\begin{abstract}
Conversion is a critical part of Evangelical theology and missiology. It has been defined as a crisis experience or a decision at a specific point in time. However, there is always an aspect of development, a process, involved. Increasingly, the phenomenon of conversion of those from non-Christian backgrounds, for example from other world religions, indicates that how they become followers of Christ is often characterised by a gradual journey, sometimes accompanied by visions and dreams. This paper looks at the phenomenon of conversion through a historical and missiological lens to explain and understand the dynamics of the conversion.
\end{abstract}

KEY WORDS: conversion, Evangelical, proselyte, convert, allegiance

\section{Introduction}

Historically, the objective of Christian missions has been to ensure conversions and the planting of churches among all nations and ethnic groups. However, the understanding of what is meant by conversion has varied. Whilst some Christian denominations no longer emphasise conversion, and have ceased to do evangelism as part of the mission of the church, others, mainly Evangelical and Pentecostal churches, emphasise a decision or a crisis experience as being foundational to what it means to be a follower of Christ.

According to the traditional Evangelical approach, to become a Christian believer, a person needs to acknowledge his or her sinfulness and accept the forgiveness that God offers in Christ. This is evidenced through a cognitive acknowledgement of these truths, believing, and being followed by a prayer accepting Christ as Saviour. Specific verses, such as Acts 16:31 and John

* RUPEN DAS (DMin 2014, Acadia Divinity College, Acadia University, Canada) is PhD candidate at the Vrije Universiteit, Amsterdam. He is on the faculty of International Baptist Theological Study Centre Amsterdam, and a Research Professor at Tyndale University College and Seminary, Toronto. Email: rupen.das@gmail.com. 
3:16, encourage a person to believe in Jesus Christ. Thus, conversion or being 'born again' is understood predominantly as an event that can be placed in a specific context and a moment in time.

However, many of the experiences of those from non-Christian traditions highlight a different process of how the converts started worshiping Christ. Recent studies of conversion experiences of Muslims (Woodberry and Shubin 2001; Woodberry et al. 2007; Garrison 2014), Hindus (Iyadurai 2015), and Buddhists (Hilderbrand 2016) into Christianity identify a number of phenomena. Whilst the details vary, many described supernatural experiences such as dreams, visions, physical healing, and miracles as being pivotal in their turning to Christ. Some also described experiencing love and acceptance from Christians, as well as observing the quality of their lives, as being critical factors in their conversion. At some point, most would also have heard the Bible being taught or preached either in person, or via the internet, radio, or TV. This would have clarified what they had experienced. In most cases, conversion was a process, with events and decisions along the way.

Though Evangelicals do not exclude a view of conversion as a process, this usually does not fit into their traditional mould of interpretation. In the following sub-sections an attempt will be made to explore which examples from the history of mission would provide insights to explain conversion experiences. This paper will focus on the phenomenon of conversion primarily in Protestant missions, though it will also briefly look at conversion in church history prior to the Reformation. The word 'conversion' in Evangelical terminology is comparatively new. It was coined by Jonathan Edwards to refer to decisions made for Christ at the revival meetings he held in the early 1700 s. It then became an integral part of the language to describe $19^{\text {th }}$ century American evangelicalism (Hill 1986: 1).

The present-day literature on conversion, which received much discussion around the 1990s and the early 2000s, is usually connected with the topic of contextualisation. Whilst conversion from a social science perspective has been studied periodically since the last decades of the 19th century, there is only limited literature on the dynamics of conversion in missional practice. Nevertheless, some recent volumes have pushed the boundaries of an Evangelical understanding of salvation and conversion (Stackhouse 2002; Davidson and Rae 2011; Bates 2017). Other literature on conversion has been on insider movements and, as mentioned, conversions from the major religions. This author adheres to an Evangelical perspective and the conclusions will look at some implications for the traditional Evangelical understanding of conversion. 


\section{Understanding the term 'Conversion' \\ Biblical Foundations: 'Proselyte' and 'Convert'}

Paying attention to Biblical notions of 'proselyte' and 'convert' could be helpful for clarification of the terminology. There is a difference between a convert and a proselyte. The origin of the term proselyte is from the Greek and refers to heathens and gentiles becoming Jews (Harper 2016). Proselytes were changing their religious beliefs, joining a new faith, and as a result changing their social location. According to German theologian and textual critic, Ernst von Dobschutz, the original Greek term proselytos is found in the Septuagint, probably borrowed from colloquial speech as the equivalent for the Hebrew ger, meaning stranger, someone who was not a Jew (von Dobschutz 2005). In the present-day culture, the word 'proselytism' has come to mean an illegitimate form of evangelism involving an element of 'sheep-stealing' amongst Christian denominations.

The words 'conversion' and 'proselytism' have often, though inaccurately, been used interchangeably. Missiologist Andrew Walls writes that the word 'conversion' has been used either as an 'external act of religious change' or as a 'critical internal religious change in persons'. However, he makes a distinction between a convert and proselyte. Referring to the book of Acts he states that those who responded to the Gospel were not joining a religious movement but were converts affiliated with Jesus Christ. The new Gentile believers were not required to become Jews and thus were not proselytes. As converts their identity, loyalty, and obedience was now exclusively to Christ (Walls 2004: 2-5). Whilst proselytism is an act of changing one's religious affiliation and social position, conversion signifies an internal human dynamic, which may have implications regarding one's religious affiliation. Missiologist Joshua Iyadurai refers to conversion as a 'transformative religious experience'.

This knowledge gained is not a rational understanding of religious truths. This knowledge is possible only through direct experience of God, which cannot be imparted or articulated in verifiable philosophical propositions. This knowledge is given to converts at the divine-human encounter despite their antagonism against Christianity (Iyadurai 2015: 21).

George Carey, a former Archbishop of Canterbury, states that there are three word roots that are at the heart of the concept of conversion. These are 'to turn', 'to repent', and 'to be born again'. There are also other words that have a bearing upon the concept of conversion, such as 'to believe' and 'to confess' (Carey 1986:11). The first term is the Greek word epistrepho which means to turn. It has connotations of change of mind and heart, and of physically turning. In the New Testament, the theological concept is understood as turning to God and away from idols (Carey 1986: 12). 
Both epistrophe and metanoia were translated as conversio in Latin, and thus entered the English language (Kling 2014: 599-600). Nevertheless, they are not full synonyms, though they describe the same phenomenon. Metanoia means to have second thoughts, to repent. John the Baptist preached metanoia, urging people to turn from their old life of sinful living and believe in the good news (Mark 1:15). Peter at Pentecost preached, 'repent and be baptized' (Acts 2:38). In Acts 3:19 and 26:20, the idea of repentance and turning appear together (Carey 1986:11). The third term 'born again' (John 3:16) or 'new birth' is used primarily in the New Testament, though the ideas of renewal and regeneration are found throughout the Bible (Carey 1986: 13-14).

Though present day sociological, psychological and missiological interpretations have revealed the complexity of the term 'conversion', the biblical framework helps to balance the discussion, at least from an Evangelical perspective. Missiologist Chris Wright argues that the nature of conversion in the New Testament is the radical rejection and displacement of all other gods, inclusion in the community of God's people, allegiance to Christ, and a radical ethical transformation (Wright 2004: 18-19). It is a process of radical transformation of the individual. Richard Peace summarises that metanoia must be combined with pistis_faith—in order to bring about epistrophe (Peace 2004:8).

\section{Ecumenical Understandings of Conversion}

Christian denominations have different understandings of conversion. New Testament scholar Scott McKnight writes that there are three orientations to conversion: personal decision, socialisation, and liturgical acts (McKnight 2002: 102). Peace uses these three orientations to look at the missiological challenges they provide.

According to Peace, conversion through a personal decision, which is comparatively sudden, is central to Evangelical tradition and theology. Certainly, there are cases that challenge this view, but in general Evangelicals tend to favour an experience that often can be dated and is an encounter of some sort-with truth, with Jesus, with conviction of sin. The strength of this orientation is its simplicity and functionality. It provides clear guidance of how to believe and what to believe in order to become a Christian. The Pentecostals' view of conversion is similar, but tends to be much more intense, and sometimes accompanied by signs of God's power indicating that He is active in one's life (Peace 2004: 8-9).

The second orientation is conversion by socialisation. Peace refers to Scott McKnight who opens another facet to the discussion: that many Christian traditions see conversion as a process of nurture and socialisation rather than a decision. Where there is infant baptism, the decision made by 
the individual later in life has more to do with alignment with the beliefs of the community than with a personal religious crisis experience (Peace 2004: 9).

Peace finally describes the use of liturgical acts-in Roman Catholic, Anglican and Orthodox Churches-to signify conversion. Whilst there is some overlap with the socialisation process, liturgical acts, such as baptism and partaking of the Eucharist for the first time, are official rites of passage and initiation into the Church. Children born within Catholic families do not need to be converted since they have been baptised as children, but have traditionally undergone confirmation and other rites of passage. Moreover, conversion does not seem to be part of the 'functional vocabulary' of the Orthodox Church. Peace quotes Russian Orthodox theologian and philosopher Aleksei Khomiakov: 'No one is saved alone. He who is saved is saved in the Church, as a member of her and in union with all her other members' (Peace 2004: 10-11). In this way, conversion is equated with joining the church.

Peace concludes that no one tradition encompasses a full understanding of conversion, as 'all views contribute important parts to a holistic understanding of conversion and hence of evangelism':

Holistic evangelism will invite people into the kingdom of God. It will invite them to turn to Jesus in repentance and faith in the context of the community of God's people, which has worship and the sacraments at its center. Such evangelism will invite nominal Christians to become active followers of Jesus. It will engage genuine seekers as they explore the issues that will move them forward in their pilgrimages. It will not settle for cultural faith (Peace 2004: 12).

\section{World Council of Churches and Ongoing Discussion}

The understanding of conversion, so central to Evangelical theology and missional practice, has been questioned as to its necessity in a modernising and pluralistic world by many member denominations of the World Council of Churches (WCC). At the founding Assembly of the WCC in Amsterdam in 1948, there was an unequivocal call for evangelism. Its understanding of conversion was articulated when it stated that the Church is given the privilege 'of making Christ known so that each is confronted with the necessity of a personal decision, Yes or No'. However, at the 1952 International Missionary Council (IMC) in Willingen, Germany, the term 'conversion' did not appear in any of the final reports. Missiologist Arthur Glasser quotes David Jenkins, then at the WCC: 'Mission is the activity of God, not the conversion of men to belief, or the recruiting of men into the ranks of the saved.' (Quoted in Glasser 1986: 85). Instead, WCC urged the churches to let the focus be on Jesus-'the unique example of sacrificial personal concern and social service' (Glasser 1986: 84-86). 
The Third Assembly of the WCC in New Dehli in 1961 saw an increasing impact of Orthodox churches who considered the conversion-orientated work of Evangelical churches and mission agencies as 'unethical proselytism', especially in Orthodox majority countries. The ongoing discussion was reflected in the revised report of 'Christian Witness, Proselytism and Religious Liberty' (World Council of Churches 1960). One of the outcomes of the New Delhi Assembly was the establishment of the Commission for World Mission and Evangelism. The objective was to 'further the proclamation to the whole world of the Gospel of Jesus Christ, to the end that all may believe in Him and be saved' (Glasser 1986: 88). However, the language of conversion was marginalised. Some Asian theologians preferred the image of the Cosmic Christ who was already at work in secular history, in all cultures and religions, beyond the confines of the Church. In the publication of The Theology of the Christian Mission (Anderson 1961) none of the 27 contributors dealt with the issue of conversion. The new key-words were 'dialogue' and 'Christian presence'. The new understanding was that 'conversion must be defined in terms of a person's response to the needs of the world', rather than in the traditional language of turning to Christ in repentance and faith. 'The evidence of its reality must be expressed in action for social change and the advancement of human community' (Glasser 1986: 89).

The divergence between the WCC and the Evangelical community reached its peak at the Fourth Assembly of the WCC in Uppsala, in 1968, where the overall thrust was silence on the issue of conversion and the task of bringing people to faith in Jesus Christ. However, there were proevangelism voices. Donald McGavran reminded the Assembly in Uppsala to not 'betray the two billion' who had not heard by not sharing the Gospel with them (McGavran 1968). Preceding this, the Second Vatican Council (1962-65) had expressed concerns about diminishing missionary activity, encouraging focus again on the essentialness of conversion. German missiologist Peter Beyerhaus, in 1970, brought together a sizeable number of theologians to draft the Frankfurt Declaration, which warned against 'reduction of the Christian mission to secular humanism'. At the world mission conference in Bangkok, in 1972-73, a number of delegates verbalised similar concerns (Glasser 1986: 91-94).

There has been significant dialogue since. The efforts of Uruguayan theologian, Emilio Castro, culminated in a document entitled 'Mission and Evangelism: An Ecumenical Affirmation' which was approved by the Central Committee of the WCC in 1982. The key statement in the document was: 'The Church is sent into the world to call people and nations to repentance, to announce forgiveness of sin and a new beginning in relations with God and with neighbours through Jesus Christ. This evangelistic calling has 
a new urgency today.' (World Council of Churches 1983: 65). The understanding of conversion as the Evangelical tradition understood it was spelled out in the WCC report, emphasising the relationship between conversion and 'doing justice and loving mercy' (World Council of Churches 1983). Much of the thrust of this document came from the Hong Kong Baptist missiologist, Raymond Fung. There were other important Evangelical voices too, for example, Orlando Costas and René Padilla.

\section{Historical Understanding and Practice of Conversion in Christian Mission}

\section{Interpretations during the First Christian Centuries}

The interpretation of the notion 'conversion' has not been static through history. The very early Church, because of its Jewishness, was not concerned with inviting Gentiles to join the emerging faith community. The Gentiles who came-Cornelius, the Samaritans, and the Ethiopian eunuch-did so because of 'providential nudges' rather than any policy of evangelism. The call for conversion and repentance was for the Jews and they continued to focus on 'messianic renewal and restoration of Israel' (Walls 2004: 4). However, the situation changed after the execution of Stephen and scattering of Jewish Christ-followers. Those mainly from Libyan and Cypriot backgrounds, arriving in Antioch, began talking about Jesus to the Greeks, the Gentiles. They presented Jesus as kyrios, the Lordsomething that the Greeks understood, since that was the title used for their cultic deities. Evangelism required not only a linguistic translation but a conceptual translation also (Walls 2004: 4).

As the Greeks began to worship Jesus as Lord, there was a need to rethink their status. Were they to become proselytes? The Council of Jerusalem, in Acts 15 and Galatians 2, resolved the issue by stating that Gentiles did not have to become proselytes and keep the Jewish laws. Though the word 'convert' is lacking in these texts, the concept of the convert is introduced. Walls describes the emergence of the convert model in Galatians 2: 'Paul will not allow it even as an option for people brought up as Hellenistic pagans to adopt, on coming to Christ, the lifestyle of very good, devout, observant Jewish believers. The followers of Jesus are not proselytes. They are converts' (Walls 2004: 5). Alan Kreider argues that conversion in the Early Church involved not just a change in beliefs but also in belonging and behaviour. Because of the pagan backgrounds of those new believers in Christ 'the task of conversion was to reshape an entire way of living and system of values' (Kreider 1999: xiv-xv).

The new Christian congregations in the decades following the events in the Gospels were fairly open and welcoming communities. The persecutions, starting around 60 A.D., gradually changed the situation: open proc- 
lamations of Christian faith would have gotten congregations into 'deathly difficulty' (Kreider 1999: 13-14). Nevertheless, Christianity continued to expand. 'Rumors that God was present in Christian gatherings' may have attracted outsiders' curiosity (Kreider 2016: 109). Conversion, in this context, began to be characterised by gradual initiation. Robin Lane Fox explains:

To believe that Christians were fully won by the sight of a wonder or an exorcism is to shorten a long process and ultimately to misjudge the extreme canniness of Mediterranean men... Whereas pagan cults won adherents, Christianity aimed, and contrived, to win converts. It won them by conviction and persuasion, long and detailed sequels to the initial proof that faith could work (Fox 1996: 330).

For the Early Church, conversion was not primarily a moment or event, but a journey, an extended period of intentional formation. It started with informal contact with the potential believer, and it moved, after the candidate was approved by church leaders, to the second stage, that of a catechumen. Catechumens were supposed to leave their old allegiances and values behind. The converts received instruction for reshaping their behaviour. The next step was to receive teaching focused on belief as well as undergo exorcisms and other spiritual preparation culminating in baptism. Now they belonged to the Christian community and could participate in the prayers and the Eucharist. Often a fourth stage was added: introduction to the mysteries of baptism and the Eucharist (Kreider 1999: 22).

The coming of Christendom in the 4th century, changed how people became Christians and how they were initiated into the church. The Emperor Constantine's case is significant, as he was considered 'somehow' a Christian, though he remained uncatechised, and received the prescribed rites of exorcism, baptism and anointing only at the very end of his life (Kreider 1999: 36-37). In wider society, Christians were no longer a beleaguered minority. The catechetical process became shorter or was skipped altogether. This resulted in a 'large, amorphous group of unbaptized ‘Christians hesitating and temporizing, deferring the time when they would be willing to submit themselves to the rigors of conversion' (Kreider 1999: 41). As most of the population professed to be 'Christian', the focus of recruitment to the Church was on baptising infants, whom preachers would later remind of the promises made on their behalf by parents and sponsors (Kreider 1999: 94).

While church leaders preached for the need of conversion, to turn from all that kept them from a total devotion to Christ, the reality was that few could do it, even if they wanted to. How could ordinary Christian farmers or artisans abandon everything and change their lifestyle? In the 6th century, Caesarius of Arles believed that conversion was for all Christians, but was 
a requirement for clergy (Kreider 1999: 81). Indeed, right through the Middle Ages in the Latin West, the primary meaning of 'convert' was a person seeking a vocation in the religious or monastic orders (Walls 2004: 2). Though this might include momentary experiences or instantaneous spiritual illuminations, it is best described as a journey or development. It was a gradual commitment to God, turning away from worldly patterns of life. In a way, the monastery became the location of conversion.

\section{The Modern Evangelical Understanding of Conversion}

The Reformation brought a new approach to conversion into the Christian West. The Reformers tended to emphasise learning and growth in scriptural understanding. Their emphasis was not on a defining moment or special experience. Whilst in Medieval times the monastic community was central, and conversion could mean a lay person entering a monastery, or a monk or nun seeking a higher level of spiritual development (Muldoon 1997:1), for the Reformers, instead, conversion was a process as one learnt more of what it meant to live by faith, 'in the justifying grace of God'. Neither Luther nor Calvin wrote much about a theology of conversion, though, understandably, baptism was seen as a means of grace and an important part of the process of salvation (Smith 2010: 65).

The modern Evangelical understanding of conversion, building a link between a momentary event and a process of learning to live by faith, has its roots with the Puritans. Also, the Anabaptists of the 16th century emphasised the role of preaching of the Word, turning away from sins, and taking up a new life. These elements of conversion resulted in 'new birth' (Ediger 1980: 17). Some scholars have argued that for Anabaptists conversion was a crisis encounter with God, which resulted in radical personal change (Loewen 1975). However, it was Jonathan Edwards who formulated a doctrine of conversion. He wrote in 1740 :

The doctrine of conversion, or the new birth, is one of the great and fundamental doctrines of the Christian religion... because [conversion] is by Christ's express declaration absolutely necessary to their [the Christian's] salvation. Thus, the voice of reason, Scripture and experience, and the testimony of the best of men all do concur in it, that there must be such a thing as conversion (Quoted in Smith 2010: 68).

Edwards believed that conversion was the only way that spiritual transformation would occur. Similar to the Puritan way of thinking, he was convinced that 'a personal radical conversion... is the indispensable first experience of all genuine Christians' (Smith 2010: 69), and without a conversion experience there was no assurance that a person knew the salvation of God. However, there was a difference between the 17th century Puritan idea of 
conversion after a prolonged struggle and the 18th century idea of Edwards that there could be an immediate experience. In this historical context, conversion combined both sudden and continuous elements and was a protracted process usually containing various stages or moments.

John Wesley added another aspect to the modern Evangelical understanding of conversion. Because of his Puritan mind-set, he nurtured a deep commitment towards holiness as the purpose of conversion. Conversion, thus, was a true personal encounter with the living God that would transform an individual, resulting in holiness in all areas of life. Wesley's focus was on human responsibility as a response to God's initiative. For Wesley, whose heart was 'strangely warmed' on 24 May 1738 at the meeting on Aldersgate Street, conversion was an experience in a moment of time which started the journey towards holiness (Smith 2010: 71-72).

Henri Gooren writes that conversion for Evangelical and Pentecostal churches was essentially the Puritan ideal of an individualised conversion. By the time of the Second Awakening in the early 1800s the conversion model of repentance included accepting Jesus Christ as one's personal Saviour. This approach was later consolidated into the Holiness Movement. With the rise of Pentecostalism in the 1900s, this became standard practice in their churches. The distinctiveness of the early Pentecostal churches was that praying, singing, and speaking in unknown tongues-glossolaliabecame the main external markers of the conversion experience. However, for some Pentecostals, this was expected to happen at the moment of conversion, whilst for others it was located in the realm of the so called second experience (Gooren 2010: 96-99).

The Reformation and the movements that followed reaffirmed the need to personally respond to God's work by faith. The modern concept of conversion moved towards what could be characterised as a 'crisis encounter', resulting in a radical transformation of the individual. This energised the modern missionary movement and later, since World War II, became the standardised model for conversion among Evangelicals.

\section{Modern Missions and Conversions from Other Religions}

Since the late 1700 s, modern missions working in religiously pluralistic contexts used a variation of the pattern that the Early Church had used with regards to the conversion of pagans. Enquirers would receive instruction, and the sincerity of their decision to become a Christian would be discerned before they were baptised and initiated into the Church. The period of instruction would vary depending on the policies of the mission agency and the religious context. In more recent times the approach to conversion based on repentance, hearing the Word of God in preaching and accepting Christ as personal Saviour, instead of systematic 'catechetical' instruction, is 
more commonly used, whether in mass evangelism events, such as those of Billy Graham, evangelistic preaching in churches, or in personal evangelism. This conversion would then be attested by baptism by immersion.

For Evangelicals, the method did not vary whether the potential enquirer was from a nominal Christian or secular background, or was from another religion. However, the encounter with other religions, in particular Islam, Buddhism, and Hinduism, is showing that people can encounter Christ in very different ways from the traditional Evangelical model of conversion. Moreover, a Muslim convert to Christianity ibn Warraq (pen name) points out: 'A Muslim abandoning his faith for humanism or atheism is likely to give rational explanations why belief in any of the tenets of Islam is no longer intellectually tenable, and his reasons would differ substantially from a Muslim who converted to Christianity.' (ibn Warraq 2003: 91).

Missiologist Dudley Woodberry has researched extensively how and why Muslims leave Islam and embrace Christianity. He noted a number of influences. The first was that the Muslims saw a lived-out faith in Christians-in the loving relationships in Christian marriages, treatment of women as equals, a simple lifestyle, respecting local customs of not drinking alcohol or eating pork, and not touching people from the opposite sex. They were particularly attracted to the person, life and teachings of Jesus. 'Nearly half of all Muslims who have made a shift of faith allegiance have affirmed that the love of God was a critical key in their decision' (Woodberry and Shubin 2001: 15). The second influence was the experience of answered prayer, healing, and the supernatural intervention of God. Closely related to this was deliverance from demonic power in the contexts of the widespread prevalence of folk Islam. Missionary Christy Wilson mentions that Muslims love to discuss and argue issues. Yet when healing or supernatural experiences occur, they are much more open to Christ (Wilson 1994). The third influence was dissatisfaction with the kind of Islam that they had experienced, especially the fact that they perceived their religion emphasizing God's punishment more than his love. Many were also repulsed by religiously motivated violence and the imposition of Islamic law. Finally, dreams and visions played a role in the conversion of many (Woodberry et al. 2007). These elements were more decisive than intellectual arguments. Muslims often come to faith in Christ without having a full understanding of the gospel and all its implications (Garrison 2014: 235).

Kelly Hilderbrand, who conducted research on Buddhist converts to Christianity, listed three factors that contributed to their conversion-an encounter with the supernatural, contact with Christians, and dissatisfaction or incongruence with their traditional faith (Hilderbrand 2016). These results are comparable to those of Woodberry. Joshua Iyadurai, analysing the conversion narratives of persons from mainly Hindu backgrounds, had sim- 
ilar findings, with emphasis on the supernatural. The converts spoke about visions, dreams, mystical experiences, miracles, and answers to prayer as being critical points in their 'transformative conversion experience' (Iyadurai 2015).

The research on converts from all three religions shows that for most, conversion was a process punctuated with spiritual encounters and a series of decisions, rather than a single crisis event. Pieter Pikkert summarises:

...there was usually more than a single factor which led to their eventual conversion... there tended to be one specific thing which stopped them in their tracks and caused them to examine Christianity in a new light. This event then led them to embark on their sometimes complex, diverse spiritual journeys-in the course of which they often received encouragement at critical junctions-until they made their solemn decision to embrace the Christ of Christianity (Pikkert 2006: 271).

Recent research shows that becoming part of a community of Christ followers is an important aspect of the conversion process. Both the Word of God and Christian fellowship enable the converts to understand their supernatural encounters and to grow in their understanding of salvation. The new relationships are even more important as many converts from nonChristian backgrounds are rejected by their own community. Belonging to a Christian community helps them to survive as individuals and to continue to grow in their new identity (Das 2015, 2016). What is also becoming increasingly clear from these conversion experiences is that the converts respond to the person of Christ rather than only to information on the work of Christ. In the light of this, '... conversion is ultimately an experience of Christ that is mediated by the Word on one hand, and the Christian community on the other, and this coming to faith cannot be choreographed' (Smith 2010: 85).

\section{An Evangelical Consensus on Conversion}

Conversion, interpreted as a crisis event, has predominated the missional practice of Evangelicals for a long time especially since World War II. The International Consultation on 'Gospel and Culture' held in Willowbank, Bermuda, in 1978 (a follow up meeting of the Lausanne Congress in 1974) looked at the experience and understanding of conversion across cultures. The Willowbank Report states: 'Too often, we have thought of conversion as a crisis, instead of a process as well; or we have viewed conversion as a largely private experience, forgetting its consequent public and social responsibilities' (Stott 1997: 93). In addition, conversion has been trivialised, with no more than a surface change, whilst Scripture describes the radical nature of conversion, which requires a break from the past, using the language of 
death and resurrection (Stott 1997: 93-94). The influence of participants from the Majority World and religiously pluralistic contexts is evident in the section of the Willowbank Report on conversion. Rather than describing an event where one repents and accepts Christ as Saviour, the Willowbank Report states: 'We are clear that the fundamental meaning of conversion is a change of allegiance. Other gods and lords-idolatries everyone-previously ruled over us. But now Jesus is Lord. The governing principle of the converted life is that it is lived under the lordship of Christ or (for it comes to the same thing) in the Kingdom of God' (Stott 1997: 94). This changed allegiance affects a person's worldview, behaviour, and relationships.

The Report also tackles the controversial issue of power encounters, an experience that often emerges in conversions from other religions into Christianity. 'We think it vital in evangelism in all cultures to teach the reality and hostility of demonic powers, and to proclaim that God has exalted Christ as Lord of all.' (Stott 1997: 96). The document refers to the Biblical statement that the Father has exalted Christ to universal sovereignty, principalities and powers having been made subject to him (1 Peter 3:22).

The Consultation on Conversion and World Evangelization (another Lausanne Movement meeting) held in Hong Kong in 1988 made distinctions between 'insider conversions' and 'outsider conversions'. Insider conversions involve people who have a substantial set of Christian beliefs because of their upbringing or culture. Outsider conversions involve people who have little or no prior Christian knowledge, usually from non-Christian religions (Stott 1997: 223). This is an important distinction, as often the strategies and methods used to evangelise people within 'Christian' contexts were being used in religiously pluralistic contexts and with those with little or no understanding of Christianity, with limited impact. Outsider conversions are usually a process rather than a single crisis experience.

\section{Conversion as an Event or a Process?}

Throughout much of Church history conversion has been seen as a process rather than an event. Following Christ and becoming part of the Kingdom of God required not only justification by God; it had to be manifested in the person's life through repentance, turning away from idols and ideologies, and abandoning old practices and rituals. It included a significant change in behaviour, and the transformation of belief systems. This happens only over a time span. In addition, conversion was not just moral transformation, but involved encountering the living God. Scott McKnight writes, 'to enter the kingdom means a person surrenders to live under King Jesus.' But 'to live under Jesus, one must come under Jesus or 〈enter the kingdom, which 
means there is either a moment when that happens or a series of moments when conversion begins' (McKnight 2014: 160-161).

The Willowbank Report differentiates between justification and regeneration, and conversion.

Justification and regeneration, the one conveying a new status and the other new life, are works of God and instantaneous, although we are not necessarily aware when they take place. Conversion, on the other hand, is our action (moved by God's grace) of turning to God in penitence and faith. Although it may include a conscious crisis, it is often slow and sometimes laborious (Stott 1997: 79).

Arthur Glasser, reflecting on mission in the Majority World and missionplanted churches, is critical in stating that much time has been spent on establishing and maintaining clear boundaries that define who is a member of the church and who is not. This has meant identifying uniform and essential characteristics of conversion that were static. 'Right doctrine, right polity plus right action' were measurable (Glasser 1986: 26). However, what may become lost in this approach is a transformational and contextual encounter with Christ. Missiologist Paul Hiebert, with extensive experience in India, refers to this as a bounded set. He asks not only what knowledge must a non-Christian have to become a Christian, but also whether this knowledge is 'perceived in a particular way, from a particular worldview'. In a religiously and culturally pluralistic context, the question is what does it mean to be a Christian? (Hiebert 1994: 109-110). The answer to this question will also help determine how a person becomes a Christian.

Hiebert identifies four categories that define how a potential seeker relates to a community of faith (Hiebert 1994: 110-133). There are two types of bounded sets and two types of centred sets.

Firstly, Hiebert explains bounded sets with clear boundaries. This clearly defines whether a person is part of a community or not. Christians inside a bounded set (a church or denomination) are homogenous in that they believe the same doctrines and ascribe to the same behaviour. Also, bounded sets have clear boundaries — church membership-and limit non-members from certain types of participation. Conversion involves crossing the boundary into the community of faith.

Secondly, there are bounded sets with fuzzy boundaries. Here also, the beliefs and practices of the community are clearly defined. However, membership and involvement is of one of degrees. Some may affirm only some of the beliefs necessary to be a Christian whilst others may believe half or all the truths. There is a gradual movement from the edges to the centre, as a person gradually acquires the necessary beliefs, but there is no point where a person suddenly becomes a Christian. 
Figure 1. Typology of Sets (adapted from Hiebert 1994: 112)

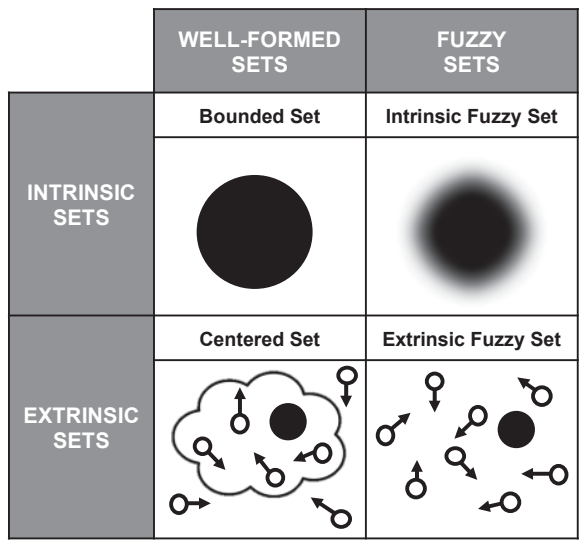

In addition, there are two types of centred sets. The Hebrew worldview was a centred set, as they knew God 'in relational terms as Creator, Judge, and Lord', and entered into a covenant relationship with God. Jesus and Paul spoke extensively about one's relationship with God and with one another. In contrast, the Greek worldview saw God as supernatural, omnipotent and omnipresent; God was distant and faith was defined by creeds (Hiebert 1994: 124-25).

Under this category, firstly, there are well-formed centred sets which are defined by a centre and everything else is relating to it. Christians are followers of Christ of the Bible. They do have a boundary defining who is part of the group and who is not, but the focus is on members moving towards Christ. Conversion, therefore, involves crossing the boundary and becoming part of the group, and turning away from evil and moving towards Christ. Christian identity is not based only on belonging to a specific group but on following Christ. Members are moving towards Christ but may vary in their distance from him as well as their knowledge and maturity.

Secondly, there are fuzzy centred sets. Fuzzy centred sets have a defined centre but unclear or no boundaries. Membership is a matter of degreesall the way from full membership to non-membership. Conversion is a process of gradual change and turning, rather than a decision.

Hiebert's model provides a framework to understand conversion in the event-and-process-scale. Usually in a context of cultural Christianity providing some recognition of Jesus Christ and an awareness of the Bible, conversion tends to be an event. These are insider conversions. In non-Christian cultures, conversion tends to be a process, not least because of the changes in the converts' worldview. Theologian Roger Olson defines authentic evangelicalism by its 'centrifugal center of powerful gravity and not by out- 
lying boundaries that serve as walls or fences. The centre is Jesus Christ and the gospel. People gathered around the centre or moving toward it are authentically evangelical.' (Olsen 2007: 60).

There are other models that look at conversion as a process, such as the Gray Matrix (Gray 2015). The Engel's scale provides insights into what changes occur in worldview and understanding before 'new birth' takes place (Engel and Norton 1975). Each of the models provide insight as to how people in different contexts encounter and understand God as they turn away from the deities they worship or the ideologies they follow, to worshiping the God revealed in Jesus Christ. Latin American theologian Orlando Costas summarises the process:

For the complexity of conversion does not lie in a fixed number of experiences but in the fact that it is a plunge into an ongoing adventure. Christian conversion is a journey into the mystery of the Kingdom of God which leads from one experience to another. Initiation in the journey of the Kingdom implies a plunge into an eschatological adventure where one is confronted with ever new decisions, turning points, fulfilments, and promises which will continue until the ultimate fulfilment of the Kingdom (Quoted in Stott 1980: 182).

\section{Conclusion}

In reviewing the phenomenon of conversion through historical and missiological lenses, there are some observations that would inform the traditional Evangelical understanding of how individuals become followers of Christ.

Historically, conversion was understood to be a process. Though justification and regeneration were interpreted as instantaneous (something that God does in a moment of his choosing), conversion, however, was explained as an intentional response to spiritual encounters and the truths from the Word of God. The process of transforming behaviour, relationships, worldviews, and spiritual allegiance, especially for those from non-Christian backgrounds, was an essential part of conversion. In the Early Church, this involved a period of instruction before catechumens were formally admitted into the believing community. The early Reformers, like Luther and Calvin, tended to emphasise the need of learning to live by faith, instead of focusing on a specific theology of conversion. The Puritans in the 17th century came to emphasise the role of conversion, even if this was often a long spiritual 'battle'. It was Jonathan Edwards, in the 1700s, and later the Holiness movement, in the 1800 s, that helped to establish the notion that conversion was predominantly a crisis event or a decision, even if they did not fully exclude a continuous element. The shift towards 'sudden conversions' is partly explained by the fact that the contexts were highly Christianised and repentance and turning to Christ would therefore be considered insider conversions, to use Lausanne Movement terminology. 
The more recent experiences of converts from non-Christian backgrounds go back to the understanding of conversion as a process. They would fit the mould of 'well-formed centred sets' in Hiebert's model. At some point the convert crosses a boundary and becomes member of a Christian community-justification and regeneration take place. However, the process of conversion, as the person undergoes personal transformation whilst becoming a follower of Christ, involves encounters, experiences and decisions both before and after the moment of justification. An Evangelical understanding of conversion needs to take into account context, which influences whether conversion is perceived in a language of a process, an event, or some combination of both.

Some denominations today may not use the term conversion but would nurture and socialise children so that they are confirmed in their faith. They may use liturgical acts to symbolise a person joining the church and being saved. However, what the practice of the Early Church, the crisis or power events of Evangelicals and Pentecostals, and the recent conversion experiences of those from non-Christian backgrounds highlight is that conversion is an encounter with the living God revealed in Christ. It is experienced as a response to the reality of God who is present and accessible, rather than a deity who is distant. Evangelism has often focused on the presentation of information about salvation and requesting a personal belief in the facts. Evangelicals need to also provide space for individuals to encounter the reality of God, and not only seek an intellectual acknowledgement of specific truths.

Finally, Evangelicals differentiate between the moment of justification or being 'saved' from the process of discipleship (also referred to as sanctification). Whilst Evangelical theologians would agree that salvation consists of justification, sanctification, and glorification, in practice they would often consider conversion and justification as overlapping. Nevertheless, the Early Church and recent conversions from non-Christian backgrounds highlight that conversion is more than just being 'saved'. It includes transformation: focusing not only on the afterlife, but on being obedient to Christ here and now. The emphasis is not on salvation but on changed allegiance; from the deity or ideology they used to worship to the living God revealed in Christ whom they follow now (Bates 2017). Evangelicals are rediscovering a broader and more dynamic understanding of conversion and salvation.

\section{Bibliography}

Anderson GH (1961) Theology of the Christian Mission. London: SCM Press. 
Bates MW (2017) Salvation by Allegiance Alone: Rethinking Faith, Works and the Gospel of Jesus the King. Grand Rapids, MI: Baker Academic.

Carey G (1986) A Biblical Perspective. In Hill M (ed) Entering the Kingdom: A Fresh Lookat Conversion. Middlesex: MARC Europe.

Das R (2015) Impact of the Local Church Showing Compassion: Lessons from the Syrian

Crisis. SEEDBED: Practitioners in Conversation 29(1): 43-50.

Das R (2016) Refugees: Exploring Theological and Missiological Foundations. Journal of European Baptist Studies 16(2):33-37.

Davidson I and Rae ME (2011) God of Salvation: Soteriology in Theological Perspective. Surrey: Ashgate Publishing Company.

von Dobschutz E (2004) Proselytes. Christian Classics Ethereal Library, http://www.ccel.org/s/schaff/encyc/encyc09/htm/iv.v.xlii.htm (Accessed 1 July 2016).

Ediger G (1980) Conversion in Anabaptist and Mennonite History. Direction: A Mennonite Brethren Forum 9(4):16-23.

Engel JF and Norton W (1975) What's Gone Wrong with the Harvest? A Communication Strategy for the Church and World Evangelism. Grand Rapids, MI: Zondervan Publishing House.

Fox RL (1987) Pagans and Christians. New York, NY: HarperCollins.

Garrison D (2014) A Wind in The House of Islam: How God Is Drawing Muslims Around the World to Faith in Jesus Christ. Monument, CO: WIGTake Resources.

Glasser AF (1986) The Conciliar Debate. In Hill M (ed) Entering the Kingdom: A Fresh Look at Conversion. Bromley, England: MARC Europe, pp. 84-97.

Gooren H (2010) Conversion Narratives. In Bergunder M et al. (eds) Studying Global Pentecostalism: Theories and Methods. Berkeley, CA: University of California Press, pp. 93-112.

Gray F (2015) The Gray Matrix, http://thegraymatrix.org/?page_id=19 (Accessed 14 February 2017).

Harper D (2016) Proselyte. Online Etymological Dictionary, http://www.etymonline.com/index.php?term=proselyte (Accessed 1 July 2016).

Hiebert GP (1994) Anthropological Reflections on Missiological Issues. Grand Rapids, MI: Baker.

Hilderbrand KM (2016) What Led Thai Buddhist Background Believers to Become Christians: A Study of One Church in Bangkok. Missiology: An International Review 44(4): 400-415.

Hill M (1986) Entering the Kingdom: Then and Now. In Hill M (ed) Entering the Kingdom: A Fresh Look at Conversion. Middlesex: MARC Europe, pp. 1-8. 
ibn Warraq (2003) Leaving Islam: Apostates Speak Out. New York, NY: Prometheus Books.

Iyadurai J (2015) Transformative Religious Experience: A Phenomenological Understanding of Religious Conversion. Eugene, OR: Pickwick Publications.

Kling DW (2014) Conversion to Christianity. In Rambo LR and Farhadian CE (eds) The Oxford Handbook of Religious Conversion. Oxford: Oxford University Press, pp. 599-622.

Kreider A (1999) The Change of Conversion and the Origin of Christendom. Eugene, OR: Wipf and Stock Publishers.

Kreider A (2016) The Patient Ferment of the Early Church: The Improbable Rise of Christianity in the Roman Empire. Grand Rapids, MI: Baker Academics.

Loewen JA (1975) Socialization and Conversion in the Ongoing Church. In Loewen JA (ed) Culture and Human Values: Christian Intervention in Anthropological Perspective. Pasadena, CA: William Carey Library, pp. 235-251.

McGavran DA (1968) Will Uppsala Betray the Two Billion? Church Growth Bulletin 5(IV): 233-241.

McKnight S (2014) Kingdom Conspiracy: Returning to the Radical Mission of the Local Church. Grand Rapids, MI: Brazos Press.

McKnight S (2002) Turning to Jesus: The Sociology of Conversion in the Gospels. Louisville, KY: Westminster John Knox Press.

Muldoon J (1997) Introduction: Conversion of Europe. In Muldoon J (ed) Varieties of Religious Conversion in the Middle Ages. Gainsville, FL: University Press of Florida, pp. 1-12.

Olsen RE (2007) Reformed and Always Reforming: The Postconservative Approach to Evangelical Theology. Grand Rapids, MI: Baker.

Peace RV (2004) Conflicting Understandings of Christian Conversion: A Missiological Challenge. International Bulletin of Missionary Research 28(1): 8-10.

Pikkert P (2006) Protestant Missionaries to the Middle East: Ambassadors of Christ or Culture? PhD Thesis, University of South Africa.

Rambo LR and Farhadian CE, eds (2014). The Oxford Handbook of Religious Conversion. Oxford: Oxford University Press.

Smith GT (2010) Transforming Conversion: Rethinking the Language and Contours of Christian Initiation. Grand Rapids, MI: Baker Academic.

Stackhouse JG (2002) What does it mean to be Saved? Broadening Evangelical Horizons of Salvation. Grand Rapids, MI: Baker Academic.

Stott JRW (1980) Conversion as a Complex Experience. In Stott JRW and Coote R (eds) Down to Earth: Studies in Christianity and Culture. Grand Rapids, MI: Eerdmans Publishing.

Stott JRW (1997) Making Christ Known: Historic Mission Documents from the Lausanne Movement, 1974-1989. Grand Rapids, MI: Eerdmans Publishing. 
Walls AF (2004) Converts or Proselytes? The Crisis over Conversion in the Early Church. International Bulletin of Missionary Research 28(1): 2-6.

Wilson JC (1994) Muslims Who Came to Christ. Missionary Monthly (March).

Woodberry D and Shubin R (2001) Why I Chose Jesus. Mission Frontiers, http://www.missionfrontiers.org/2001/01/muslim.htm (Accessed 13 April 2015).

Woodberry JD Shubin R and Marks G (2007) Why Muslims Follow Jesus: The Results of a Recent Survey of Converts from Islam. Christianity Today, http://www.christianitytoday.com/ct/2007/october/42.80.html (Accessed 13 April 2015).

World Council of Churches (1960) Revised Report of the Commission on 'Christian Witness, Proselytism and Religious Liberty'. Ecumenical Review 13(1): 79-89.

World Council of Churches (1983) Mission and Evangelism: An Ecumenical Affirmation. International Bulletin of Missionary Research 7(2): 65-71.

Wright CJH (2004) Implications of Conversion in the Old Testament and the New Testament. International Bulletin of Missionary Research 28(1): 1419. 